\title{
Library Service in Perspective
}

\author{
BY JAMES R. KENNEDY
}

A FRIEND of librarians once suggested that a librarian is an unusual kind of traffic engineer, because he tries to arrange collisions, collisions between ideas and people. ${ }^{1}$ It is these collisions which give librarians a sense of excitement and sometimes turmoil.

A primary cause of turmoil for librarians is the fact that we are public servants. We serve not merely one boss but all the readers who make up our public. Our situation as everybody's servant is dramatized by the crowds and the ringing telephones at peak hours at the different service desks. Because the reference and circulation departments are on the firing line, they are most aware of their calling to be servants, but so are the other departments. The technical services are the indispensable "man-behind-the-manbehind-the-gun." They are the so-called hidden services. If they have not done their part, the public service librarians may be powerless to get the right book to the right person at the right time. So we see that all of us are either directly or indirectly serving the public.

It is interesting to note that as librarians we have stressed the service aspects of our work. This is evident in our language, where the word "service" recurs in many phrases: technical services, reference service, reader's advisory service, the Library Services Act, the Columbia University school of library service, etc. Librarians sometimes use the word service as a synonym for such impersonal words as process or operation, ${ }^{2}$ but they also use the word in the very personal

\footnotetext{
${ }^{1}$ Halford Edward Luccock, "Salute to Librarians," Christian Century, LXXIII (March 14, 1956), 328.

${ }^{2}$ Maurice F. Tauber and Associates, Technical Services in Libraries (New York: Columbia University Press, 1954), p.4.
}

Mr. Kennedy is Business and Social Science Librarian in Drexel Institute of Technology.

sense that "direct contact is made with patrons." 3 Using the word service in the latter sense, Raynard C. Swank wrote, "Service is a cardinal principle of American librarianship." And service is surely fundamental to a fully developed professional philosophy, which Jesse H. Shera called "the great need of the library profession today."5

But granted that a librarian's purpose is to be a servant and to serve his people, what does it mean to be a servant? Paradoxically, twentieth century Americans understand this word servant to connote both shame and glory. A domestic worker is known as a servant, and finding a good servant is a problem for Americans, partly because the domestic servant is considered to be at the bottom of the ladder by us status seekers. When we find a servant we give him dignity by calling him an "employee," not a "servant."

In contrast, we find that servant is one of the honored words in our Judeo-Christian heritage. Servant is one of the key words of the Bible. In the Old Testament, God sometimes addressed His chosen people through the prophets in the words, "My servant Israel" (Isaiah 49:3). The Israelites knew themselves to be a servant people. When God revealed Himself to

${ }^{3}$ A.L.A. Glossary of Library Terms (Chicago: ALA, 1943), p.125.

"Raynard C. Swank, "Six Items for Export," $L i$ brary Journal, LXXXVIII (February 15, 1963), 714.

'Jesse H. Shera, "Diagnosis: A Survey of Opinion on the Major Problems of the Library Profession," Library Journal, LXXXVIII (January 1, 1963), 50.

' Russel Lynes, "How America 'Solved' the Servant Problem," Harper's, CCVII (July 1963), 54. 
Isaiah, Isaiah knew that God was calling him to serve and he responded, "Here I am; send me" (Isaiah 6:8). At Christmas we remember one who said, "He that is greatest shall be your servant" (Matthew 23:11). Part of the greatness of Christ is that though many wanted him to be their king, he said he "came not to be ministered unto, but to minister" (Mark 10:45). Those who follow Christ are also called to a life of service. The Christian's motive for serving is not the hope of earning heaven, but sheer gratitude for all that God has given him. "What hast thou that thou didst not receive?" (I Corinthians $4: 7$ ).

But is all this theology necessary? There are many who speak of service without referring to the word's divine dimensions. Ray L. Carpenter, for instance, wrote a lengthy and important master's thesis on the concept of service in librarianship ${ }^{7}$ and never referred to the Biblical concept of service. Swank wrote that "the attitude of service . . . is simply the attitude of helpfulness, the motive of being useful to other people." But is service this simple? When we are tested by the most trying times, is our motive strong enough and pure enough to endure, when it is not strengthened and purified by God? Are there not times when the demand for our services becomes very great and causes turmoil within us? Then we are tempted to deny that we are servants. Then we are tempted to try to get away from this frustrating situation and "take it easy." It is one of the mysteries of life, however, that we can find meaning and fulfillment only in the midst of the conflict and its frustrations. Only when we place ourselves under the burden of our work do we find relevant the words of Christ, "Come unto me, all ye that labor and are heavy-laden and I will give you rest" (Matthew

\footnotetext{
${ }^{7}$ Ray L. Carpenter, "The Concept of Service in Librarianship" (Master's thesis, University of North Carolina, 1959), 60p.

${ }^{8}$ Op. cit.
}

11:28). Brother Lawrence, a cook's helper in a monastery, was one obscure Christian who found rest in God in the midst of the turmoil of his work. In the booklet, The Practice of the Presence of God, he is quoted, "The time of business does not with me differ from the time of prayer, and in the noise and clatter of my kitchen, while several persons are at the same time calling for different things, I possess God in as great tranquillity as if I were upon my knees at the blessed sacrament." If our motive is to serve our readers in the presence of God, then we shall find that our motive is both purified and strengthened.

At this point another temptation needs to be resisted. Just as the librarian ought not to deny that he is a servant, he also ought not to behave as if he were nothing but a servant. The librarian who is serious about service may be tempted to make himself a martyr to the needs of others. The way of wisdom here is to recognize that the servant himself has a need to be served. The servant has needs for privacy, warm human relationships, and opportunity for personal development. To neglect this is to be overcome by the pressure of work, so that one serves as a functionary rather than as a complete person.

If we agree with Socrates that "the unexamined life is not worth living," we shall want to ask ourselves some searching questions regarding our service. Public service librarians might ask themselves such questions as these: (1) Am I diligent in serving each reader completely and in presenting a friendly, helpful manner? (2) Do I encourage the spirit of inquiry, or do I make the inquirer feel that his question is uninteresting or stupid? (3) Do I cultivate my imagination and initiative to learn the reader's real needs or am I content simply to repeat the rehearsed response? Librarians in the "hidden services" might ask themselves

(Continued on page 114) 
Some librarians no doubt object to using library space to display and promote the fine arts. To them it represents an intrusion on the library "sanctum sanctorum." One must judge such projects, however, in their settings, where specific differences overrule general library beliefs or practices. First of all, Northwestern Michigan College is a two-year community college without a fine arts building, located in a small city that has no art gallery or museum. In such an area, devoid of an art gallery within several hundred miles, the display and sale of art objects in the library assumes a cogency that would not be justified in more culturally-endowed urban areas where facilities for the preservation and presentation of art already exist.

From an academic standpoint it also befits a community college library to patronize the arts if the opportunity arises and the space exists. One of the most pressing tasks of a two-year college is to provide its students with an educational and cultural experience that approximates that in a four-year college or university experience. Exposing the two-year student to at least a few of the cultural advantages

\section{Perspective ...}

(Continued from page 92)

such questions as these: (1) Do I take such care in my work that a minimum number of books are lost due to my typing errors, wrong labeling, or inaccurate cataloging? (2) Am I trying to keep the proper division of my time between socializing with my fellow workers and doing my job? Are too many books or periodicals not reaching the shelves because I have wasted my time? (3) Am I engaged in a systematic study program in order to improve my skills? that his four-year counterparts enjoy will certainly assist rather than shortchange him when he does transfer to a university where he will have to compete and associate with individuals who have lived and studied in richer cultural environments.

The effects of original art display are far from immediate or measurable in a setting that has never had such a program. We are convinced, however, that our humble beginning will accrue interest and eventually pay dividends-possibly a fine arts center at Northwestern Michigan College. At least, our hope is that Eskimo art proceeds will be parlayed into even greater benefits for our college and community during the next decade. A recent letter concerning our library exhibit series from August Heckscher, special consultant on the arts to the White House, states the challenge we are attempting to meet: "That such an undertaking should be carried on by a community college library is particularly interesting. The relationship of the college to the arts-and of the arts to the community-is a big opportunity which needs to be explored through just such initiatives as your own." 